\title{
Biostratigraphy of the Abderaz Formation Based on Heterohelicids, at Six Stratigraphical Sections in East and Center of the Kopeh-Dagh Sedimentary Basin, Northeastern of Iran
}

\author{
Mohammad Vahidinia ${ }^{1}$, Meysam Shafiee Ardestani ${ }^{2}$ \\ ${ }^{1}$ Faculty of science, Ferdowsi University of Mashhad, Mashhad, Iran \\ ${ }^{2}$ Department of Geology, Ferdowsi University of Mashhad, Mashhad, Iran \\ Email: *Vahidinia@ferdowsi.um.ac.ir
}

How to cite this paper: Vahidinia, M. and Ardestani, M.S. (2017) Biostratigraphy of the Abderaz Formation Based on Heterohelicids, at Six Stratigraphical Sections in East and Center of the Kopeh-Dagh Sedimentary Basin, Northeastern of Iran. International Journal of Geosciences, 8, 623645. https://doi.org/10.4236/ijg.2017.84034

Received: December 22, 2016

Accepted: April 27, 2017

Published: April 30, 2017

Copyright $\odot 2017$ by authors and Scientific Research Publishing Inc. This work is licensed under the Creative Commons Attribution International License (CC BY 4.0).

http:" creativecommons.org/licenses/by/4.0/

\begin{abstract}
In this study, Abderaz Formation at six stratigraphical sections, in east and center of the Kopeh-Dagh sedimentary basin, has been investigated, based on biserial planktonic foraminifera. Totally, 831 samples, with 3 meter distance, were gathered from a sequence with 2800 meter thickness. Also 4 genera and 17 species of biserial planktonic foraminifera have been identified and two biozones and two subzones recognized. Based on obtained data, the age of early Turonian-earliest Campanian for the Padeha, Abderaz village and Shorab sections, Midle Turonian-Earliest Campanian for type section, Early Turonian-Late Santonian for Qarehso section and early Turonian-Earliest Santonian for Hajgelichkhan section were determined. The least amount of planktonic foraminifera was identified at Hajgelichkhan, while the maximum amount recognized at Qarehso section.
\end{abstract}

\section{Keywords}

Kopeh-Dagh Sedimentary Basin, Abderaz Formation, Biostratigraphy, Serial Planktonic Foraminifera

\section{Introduction}

The Kopeh-Dagh sedimentary basin formed after the middle Triassic orogeny in northeast Iran. This basin began to sink along the major faults aligned in approximately the northwest-southeast direction. Four of these major active basement faults have been identified in the central and western part of the basin. Sedimentation was more or less continuous throughout the middle Jurassic-Oligo- 
cene in the eastern part of the basin, where five major transgressive-regressive sequences have been identified. [1] concluded that subsidence in the eastern part of the basin was predominantly a result of sediment loading. There is no evidence of major tectonic activity in this region; all formations are conformable, except for a few disconformities within the Cretaceous succession. These disconformities can be related to epeirogenic movement in the basin. All formations in this basin narrow from northwest to the southeast. These formations were folded during the late Alpine Orogeny and formed the structural traps of the Khangiran and Gonbadli gas fields.

The Cretaceous sediments in the Kopeh-Dagh basin are divided into nine different formations, composed mainly of sandstone, conglomerates, mudstone, limestone and dolomite, with minor amounts of evaporate. The thickness of these sediments is normally more than 4000 meters, but the sediment thickness is only approximately 2500 meters in the eastern part of the basin [2]. The Abderaz Formation is one of the main upper Cretaceous successions located in the Kopeh-Dagh sedimentary basin in northeastern Iran. Although the name of the Abderaz Formation originated from the Abderaz village 75 kilometers east of Mashhad, the Abderaz Formation is actually located in Muzduran [3]. Iranian geologists studying this formation in the Kopeh-Dagh sedimentary basin have reported various ages and thicknesses of the formation. For instance, [3] [4] [5] reported thicknesses of 188.5, 522 and 521 meters for the Abderaz Formation at Muzduran the type section. Additionally, [3] [4] [5] reported ages for this formation dating to the Turonian-Santonian, Turonian-lower Santonian and Middle Turonian-Campanian, respectively. Furthermore, a Kalantari- and Bozorgnia-based study of foraminifera indicated Turonian-Coniacian ages for the Abderaz formation at Muzduran the type section [3].

A systematic study of isolated serial planktonic foraminifera for biozonation and precise age dating in four sections of the Abderaz Formation is the major aim of this study. This study also includes a determination of the TuronianConiacian, Coniacian-Santonian and Santonian-Campanian boundaries using planktonic foraminifera, inoceramids, echinoids and ammonites. For these purposes, 135 rock samples from 540 meters of the Qarehso section, 139 rock samples from 556.5 meters of the Abderaz village section, 133 rock samples from the Muzduran section, 94 rock samples from the Shorab section, 200 rock samples from the Padeha village section and 264 samples from the Hajgelichkhan section were collected and prepared for foraminiferal studies.

\section{Lithostratigraphy}

The Abderaz Formation is one of the upper Cretaceous rock formations in the Kopeh-Dagh sedimentary basin in northeastern Iran. This basin stretches hundreds of kilometers from north to northeast Iran and into Turkmenistan and Afghanistan. The Qarehso section $\left(59^{\circ} 40^{\prime} 00^{\prime \prime} \mathrm{E}, 36^{\circ} 54^{\prime} 30^{\prime \prime} \mathrm{N}\right)$ is located on the Mashhad-Kalat Road, approximately 148 kilometers from Mashhad (Figure 1). The Abderaz Formation is 540 meters thick and contains 10 lithological units, 


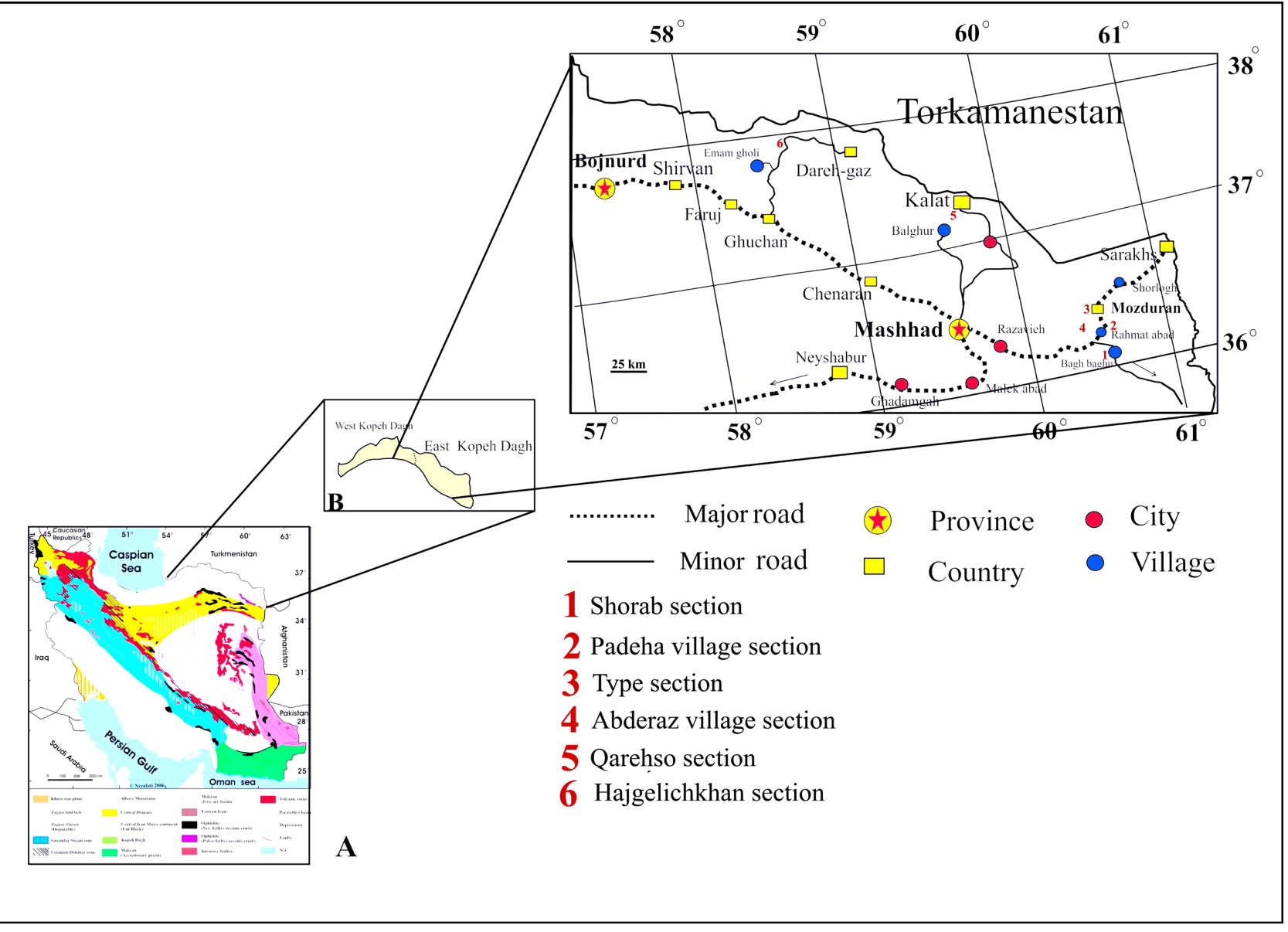

Figure 1. (A) Structure and geographic framework of Iran, showing the main sutures, structural units and geographic areas AR: Armenia, AZ: Azerbaijan, UZ: Uzbekistan, Yb: Yazd Block, Tb: Tabas Block, Lb: Lut Block, CEIM: Central-East Iranian microcontinent, OM: Oman, UAE: United Arab Emirates, KW: Kuwait. (B) Location map of the six studied sections of the Abderaz Formation in northeastern Iran.

mainly composed of light grey shale bearing inoceramus and ammonites. At the Qarehso section, as in all other sections of the Abderaz Formation, the lower contact of the formation with the Aitamir Formation is paraconform, and the upper contact with the Abtalkh Formation is continuous. The samples collected in the Qarehso section include 135 samples separated by 4-meter intervals.

The Abderaz village section $\left(60^{\circ} 24^{\prime} 38^{\prime \prime} \mathrm{E}, 36^{\circ} 05^{\prime} 35^{\prime \prime} \mathrm{N}\right)$ is located to the north of the Muzduran section. The Bazangan region is 15 kilometers beyond Muzduran. The Abderaz village section is 7 kilometers from the Bazangan region. At the Abderaz village section, the lower contact of the Abderaz Formation with the Aitamir Formation is covered, but the upper contact with the Abtalkh Formation is continuous. The Abderaz village section of the Abderaz Formation is 556.5 meters thick. In this section, 139 samples were gathered, separated by 4 -meter intervals. The Abderaz village section includes 10 lithological units.

The Muzduran section $\left(60^{\circ} 33^{\prime} 00^{\prime \prime} \mathrm{E}, 36^{\circ} 10^{\prime} 40^{\prime \prime} \mathrm{N}\right)$ is located on the Mashhad-Sarakhs Road, approximately 90 kilometers to the east of Mashhad (Figure 1 ), and contains 11 lithological units, mainly composed of light grey shale bear- 
ing inoceramus and ammonites. The thickness of the Abderaz Formation in this section is 520 meters. In the Muzduran section, as in the other regions in the Abderaz Formation, the lower contact of the Abderaz Formation with the Aitamir Formation displays disconformity, but the upper contact with the Abtalkh Formation is continuous. In this section, 137 samples, spaced at 3-meter intervals, were collected. The Shorab section is located 59 kilometers southeast of the Abderaz Village. To reach the Shorab section, one must travel along the Mashhad-Sarakh Road until the Saleh-Abad district is reached. The study area is located 33 kilometers from the Saleh-Abad district. The latitude of the Abderaz Formation at the Shorab section is $60^{\circ} 36^{\prime} 34^{\prime \prime} \mathrm{E}$ and $35^{\circ} 56^{\prime} 16^{\prime \prime} \mathrm{N}$. The lower and upper contacts of the Abderaz Formation at the Shorab section with the Aitamir and Abtalkh Formations are both conforming. The Shorab section of the Abderaz Formation is composed of light grey shale, and the previous surface is composed of white grey shale. There are high numbers of inoceramids and ammonites. In the chalk limestone bands of this formation, planktonic foraminifera are found with high frequency and low diversity. The Shorab section of the Abderaz Formation is 360 meters thick. A total of 94 samples were gathered in this section, spaced at 4-meter intervals. Abderaz Formation at Padeha section exists of the south eastern of Mashhad in Mashhad-Sarakhs road. For access to path of the studied section, we must after of Muzduran neck (placed in Mashhad-Sarakhs road) 22 kilometer went to kind of road branch to the south eastern to reach a Padeha rural and then 3 kilometer faraway of these village toward of old road following to east until arrived to Rakhshani well (placed of studied section). Abderaz Formation at mentioned section was placed in east of Rakhshani well. The geographical latitude of the studied area is $60^{\circ} 44^{\prime} 39.6^{\prime \prime} \mathrm{E}$ and $36^{\circ} 06^{\prime} 23.7^{\prime \prime} \mathrm{N}$. The Hajgelichkhan section with a thickness of $260 \mathrm{~m}\left(59^{\circ} 55^{\prime} 12^{\prime \prime} \mathrm{E}, 36^{\circ} 59^{\prime} 11^{\prime \prime} \mathrm{N}\right)$ is located on the Mashhad-Kalat road, and 40 kilometers from Dargaz area and mentioned section was placed at west of Kopeh-Dagh sedimentary basin and contains 6 lithological units mainly made up of light grey shales bearing inoceramus and echinoids.

\section{Methods}

In total, 800 samples were collected from the study areas. Depending on their lithology, the samples were washed using one of two methods. The shale and marl samples were placed in $10 \% \mathrm{H}_{2} \mathrm{O}_{2}$ for one day after being crushed into small pieces. The residues were then washed with water on screens with 125- and 63- $\mu \mathrm{m}$ meshes [6].

Chalky limestone samples were ground and boiled in $\mathrm{Na}_{2} \mathrm{SO}_{4}$ solution and were then washed with water on screens with 125- and 63- $\mu \mathrm{m}$ meshes [7].

\section{Biostratigraphy}

Seventy-seven species of planktonic foraminifera belonging to 18 genera, and 8 inoceramid species belonging to 5 genera were identified in the Qarehso section. Sixty-eight species of planktonic foraminifera belonging to 17 genera, 9 inoce- 
ramid species belonging to 3 genera in the Abderaz village section were identified. Fifty-nine species of planktonic foraminifera belonging to 18 genera, 10 inoceramid species belonging to 5 genera were identified in the Muzduran section. In the Shorab section, 51 foraminifera species belonging to 16 genera were identified. In the Padeha village section, 43 foraminifera species belonging to 10 genera were identified. In the Hajgelichkhan section, 51 foraminifera species belonging to 16 genera were identified.

The specimens are housed at the Museum of the Geology Department of the Ferdowsi University of Mashhad. Based on the index species found in this study, two biozones were differentiated, indicating an age range of the lowermost $\mathrm{Tu}$ ronian to the upper Santonian for the Abderaz Formation. In this study, the biozonation schemes of [8]-[18] were used.

The established biozones for the six intervals analyzed in this study are shown to be comparable and correlated with those previously established for the $\mathrm{Te}$ thyan realm [19]-[31] (Figure 9). These biozones are listed below.

1-1) Heterohelix globulosa subzone

Category: Interval Zone

Age: Turonian

\section{Definition:}

This zone include of first occurrence of Heterohelix globulosa to first occurrence of Pseudotextularia nuttalli.

Associations: The planktonic foraminifera found in this zone are not well preserved. The most notable species are Heterohelix globulosa (Ehrenberg 1840), H. moremani (Cushman 1938), Macroglobigerinelloides ultramicrus (Subbotina 1949), M. bollii (Pessagno 1967), Macroglobigerinelloides prairiehillensis (Pessagno 1967).

\section{Occurrence:}

The Heterohelix globulosa Zone is 51/5, 175, 272, 156, 199 and 193 meters thick in the Hajgelichkhan, Qarehso, Abderaz village, type, Padeha village and Shorab sections, respectively.

\section{Macrofauna:}

Some inoceramid species, such as Mytiloides aff. herbichi and Mytiloides sp., have been found in this zone (Figure 2).

\section{1-2) Pseudotextularia nuttalli Zone}

Category: Interval Zone

Age: Latest Turonian to Earliest Santonian

\section{Definition:}

Interval Range Zone from FO of Pseudotextularia nuttalli to the FO of Dicarinella asymetrica.

Associations: The planktonic foraminifera found in this zone are not well preserved. The most notable species are Heterohelix globulosa (Ehrenberg 1840), H.moremani (Cushman 1938), Macroglobigerinelloides ultramicrus (Subbotina 1949), M. bollii (Pessagno 1967), Macroglobigerinelloides prairiehillensis (Pessagno 1967). 


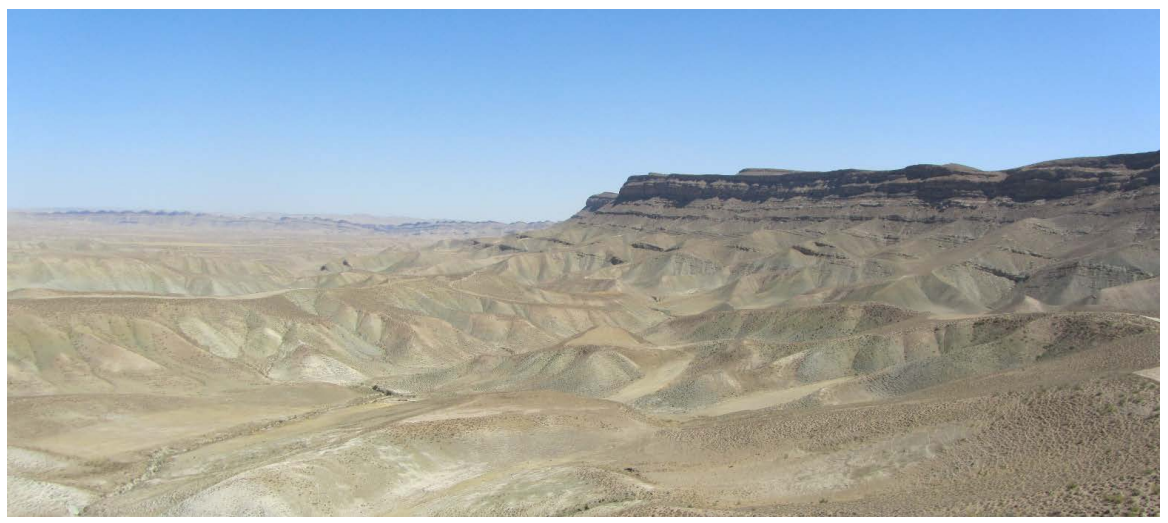

Figure 2. Panorama of the Abderaz Formation at Muzduran studied section in east of the Kopeh Dagh sedimentary basin.

\section{Occurrence:}

Pseudotextularia nuttalli Zone is $210,180,122,58,180$ and 71 meters thick in the Hajgelichkhan, Qarehso, Abderaz village, type, Padeha village and Shorab sections, respectively.

\section{Correlation:}

This zone is identical to the zone described by Caron 1985 and Abdel-Kireem et al. 1995 and the Globotruncana concavata Zone of Barr 1972. This zone corresponds to the middle region of the Globotruncana renzi Zone of Vaptzarova 1976, the lower part of the Globotruncana primitiva Zone of Wonders 1980 and the upper part of the Globotruncana schneegansi Zone of Premoli-Silva, Robaszynski et al. 1984.

\section{2) Dicarinella asymetrica Total Range Zone}

Category: Total Range Zone

Age: early Santonian to early Campanian

Author: Postuma 1971

Definition: Biostratigraphic interval characterized by the total range of the nominate taxon Dicarinella asymetrica.

\section{Occurrence:}

This zone was found in all of the sections analyzed in this study. It contains 196 meters of light grey shale, light grey marl, limey marlstone and white chalk limestone in the Qarehso section. This zone contains 168.5 meters of light grey shale and white chalk limestone at the Abderaz village section. This zone is 238 meters thick in the Muzduran section and contains approximately 108 meters of grey shale, chalky limestone and shaly limestone in the Shorab section. This zone is 337 meters thick in the Padeha section. This zone was not found at the Hajgelichkhan section.

\section{Associations:}

Archaeoglobigerina blowi, A. bosquensis, A. cretacea, A. tradinghousensis, Contusotruncana fornicata, C. patelliformis, Costellagerina pilula, Dicarinella canaliculata, Di. hagni, Di. sp., Globotruncana arca, G. linneiana, G. orientalis, G. bulloides, G. sp., Globotruncanita elevata, G. stuartiformis, Heterohelix carinata, 
H. globulosa, H. papula, H. striata, Laeviheterohelix dentata, L. pulchra, L. flabiliformis, Macroglobigerinelloides bolli, M. prairiehillensis, M. ultramicrus, M. subcarinatus, M. messinae, M. multispinus, M. sp., Marginotruncana marginata, M. coronata, M. sigali, M. schneegansi, M. sinuosa, Muricohedbergella flandrini, M. montmotensis, M. planispira, Pseudoguembelina costellifera, Pseudotextularia nuttalli, Rugoglobigerina rugosa, $R$. sp., Schackoina multispinata, Ventillabrella austiniana, Whiteinella sp.

\section{Macrofauna:}

Echinocorys ex. gr. scutata and Platiceramus ahsenensis were found in this zone with low frequency and diversity.

\section{Remarks:}

Dicarinella asymetrica is rare in the Qarehso section of the Abderaz Formation, and the last occurrence of this species was found at the base of the Abtalkh Formation. Therefore, the Santonian-Campanian boundary (the base of the Campanian stage) was placed in the Abtalkh Formation.

\section{Occurrence:}

Dicarinella asymetrica Total Range Zone is 0, 183, 151, 296, 337 and 110 meters thick in the Hajgelichkhan, Qarehso, Abderaz village, type, Padeha village and Shorab sections, respectively (Figures 3-8).

\section{Stage Boundaries}

Once all micro- and macrofauna in the Abderaz Formation were analyzed, two boundaries (the Turonian-Conician and the Coniacian-Santonian boundaries) were identified in the Qarehso and Hajgelichkhan sections, while three boundaries (the Turonian-Conician, the Coniacian-Santonian and the Santonian-Campanian boundaries) were identified in the other sections analyzed in this study.

Based on the FODs of of Dicarinella concavata, the Turonian-Conician boundary was identified in the Qarehso section. Based on the FODs of Di. asymetrica, the base of the Santonian stage was also identified in the Qarehso section.

In the Abderaz village section, three boundaries were identified. Based on the FODs of Cremnoceramus walterdorfensis walterdorfensis, C. deformis deformis and $C$. crassus crassus, along with the FOs of Contusotruncana fornicata and $C$. pateliformis, the base of the Coniacian stage was identified. The FODs of $D$. asymetrica and Macroglobigerinelloides alvarezi identify the Coniacian-Santonian boundary. Finally, based on the extinction of the Marginotruncanids and the LOD of Pseudotextularia nuttalii, the base of the Campanian stage was identified in the Abderaz village section.

In the Muzduran section of the Abderaz Formation, the base of the Coniacian stage was identified just below the first occurrence of Cremnoceramus deformis deformis, whereas the bases of the Santonian and Campanian stages were denoted by the LOD of Marginotruncanids and Ventilabrella austiniana, respectively. 


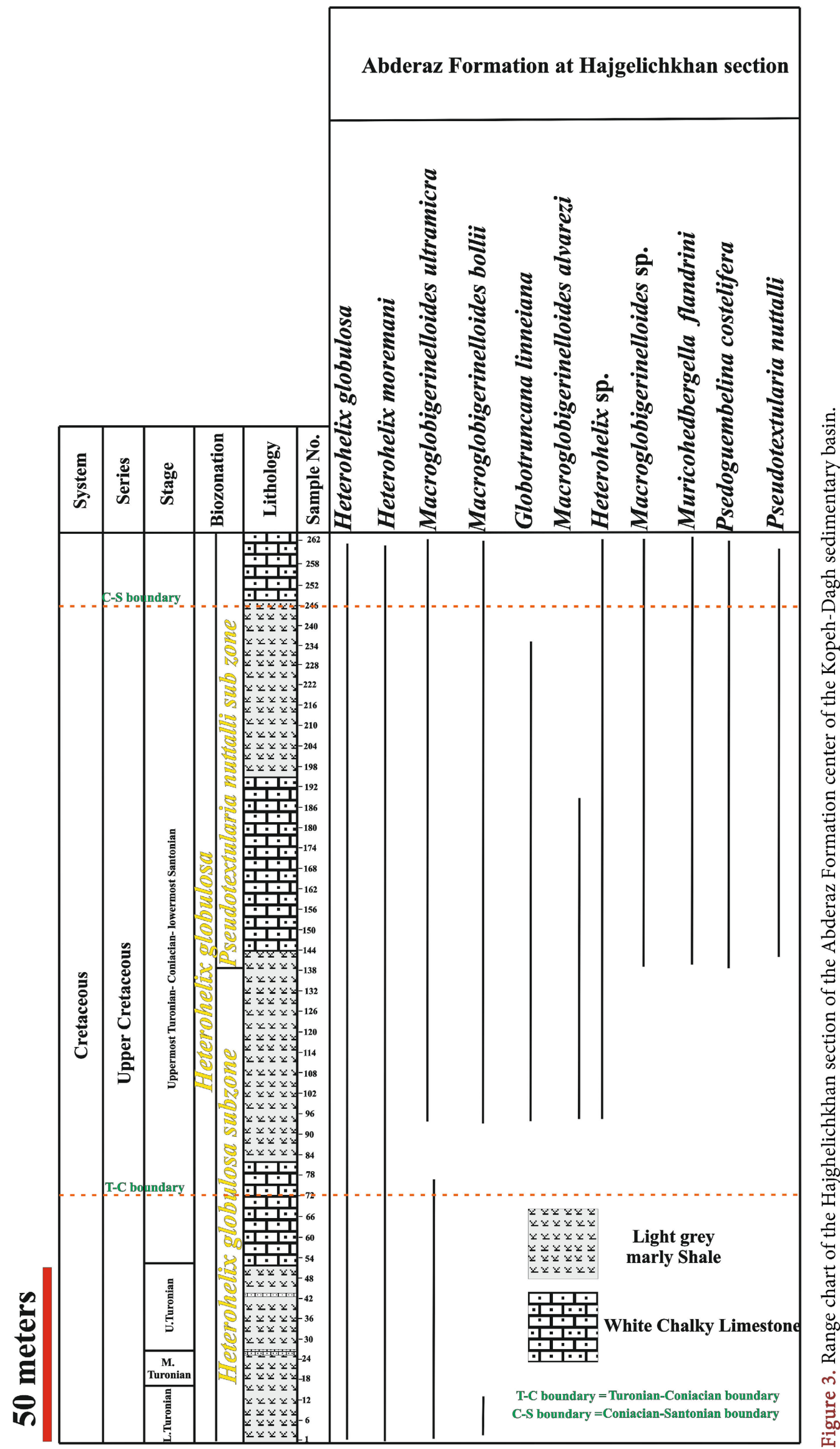




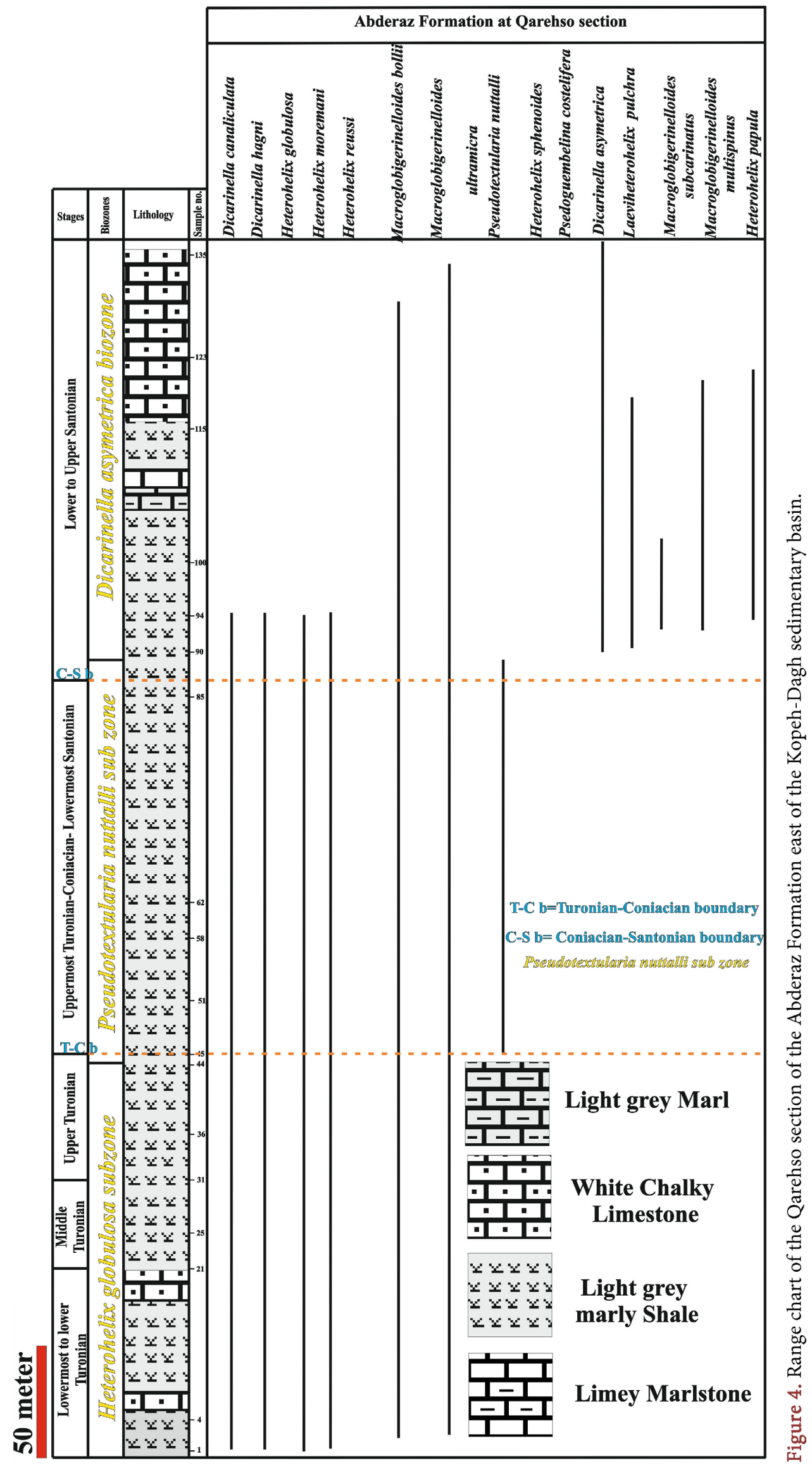




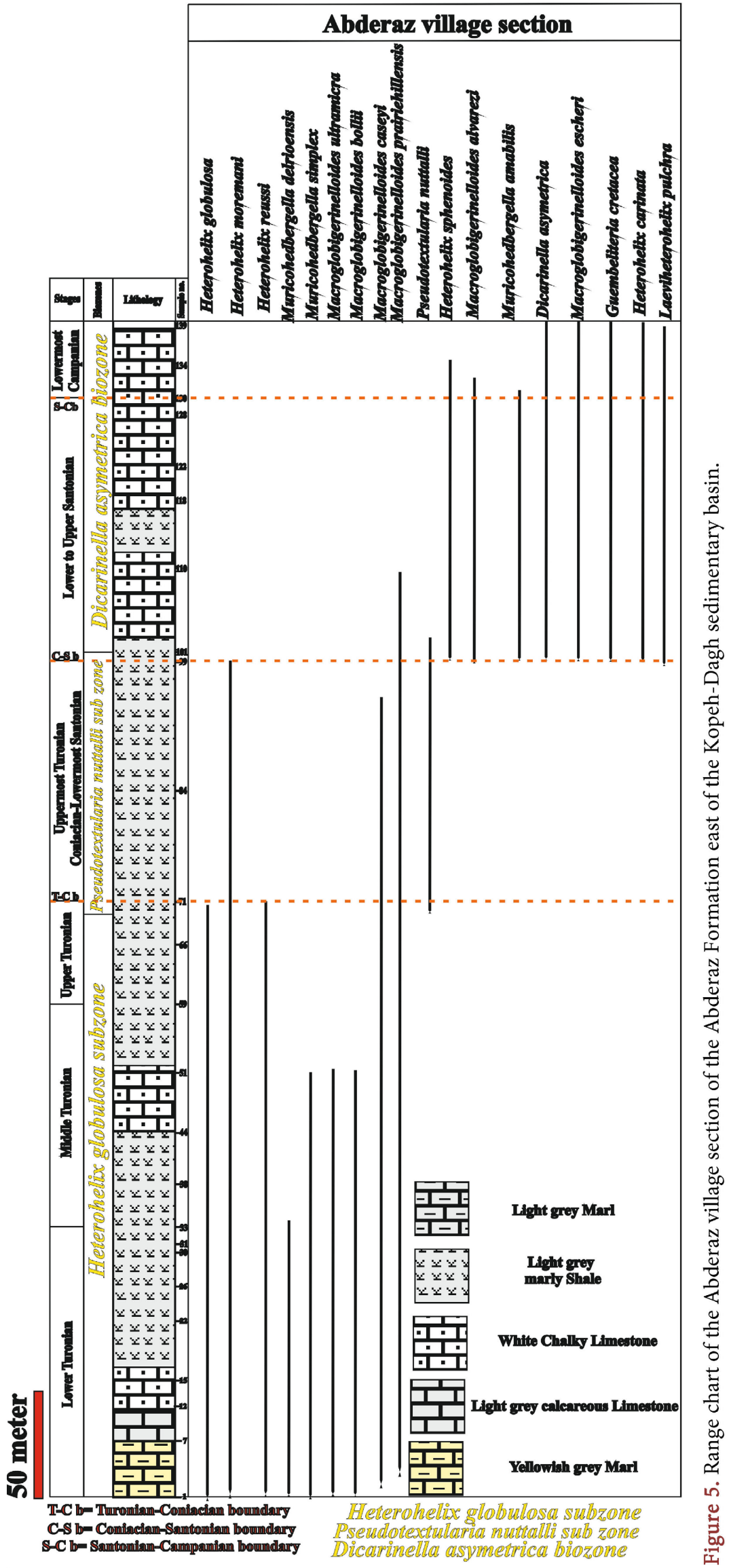




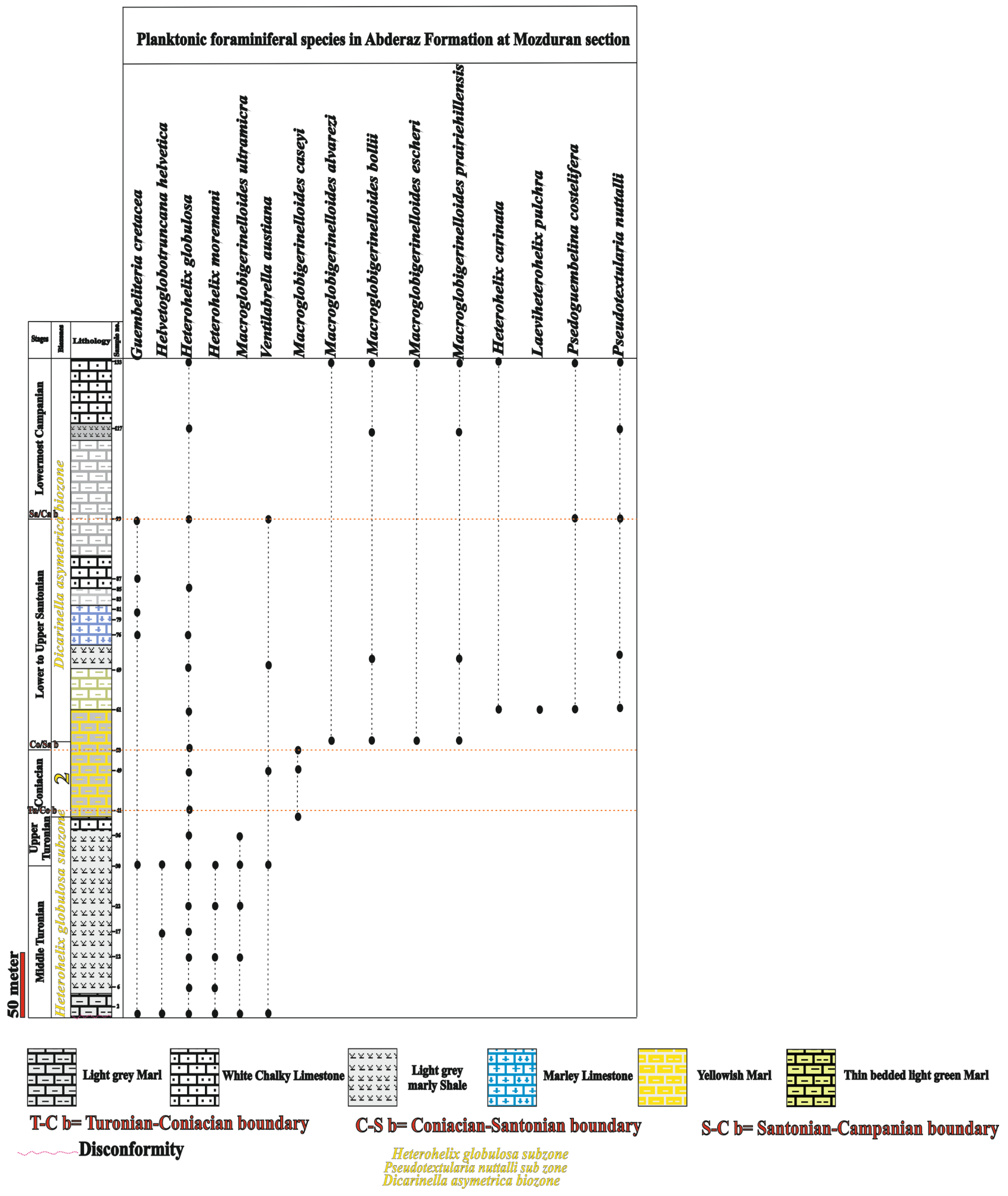

Figure 6. Range chart of the Mozduran section of the Abderaz Formation east of the Kopeh-Dagh sedimentary basin. 


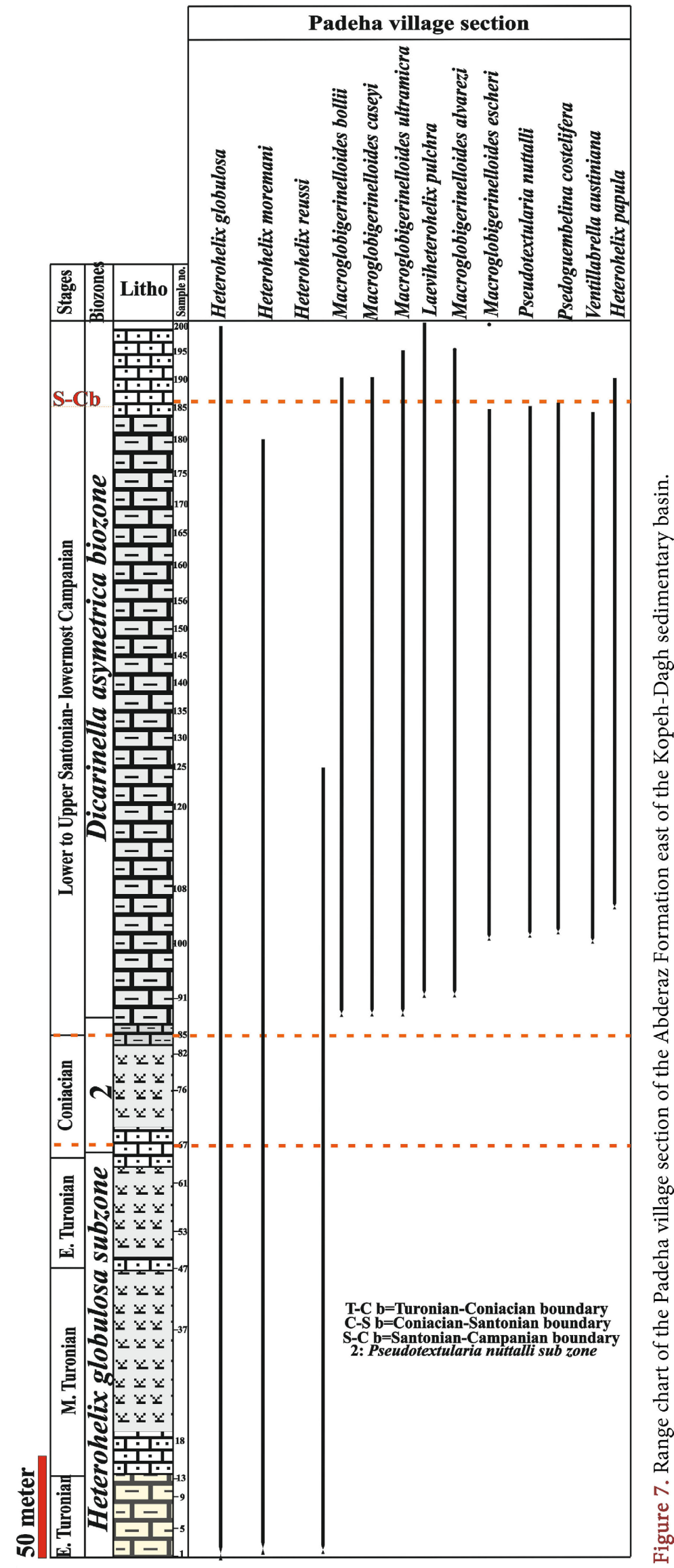




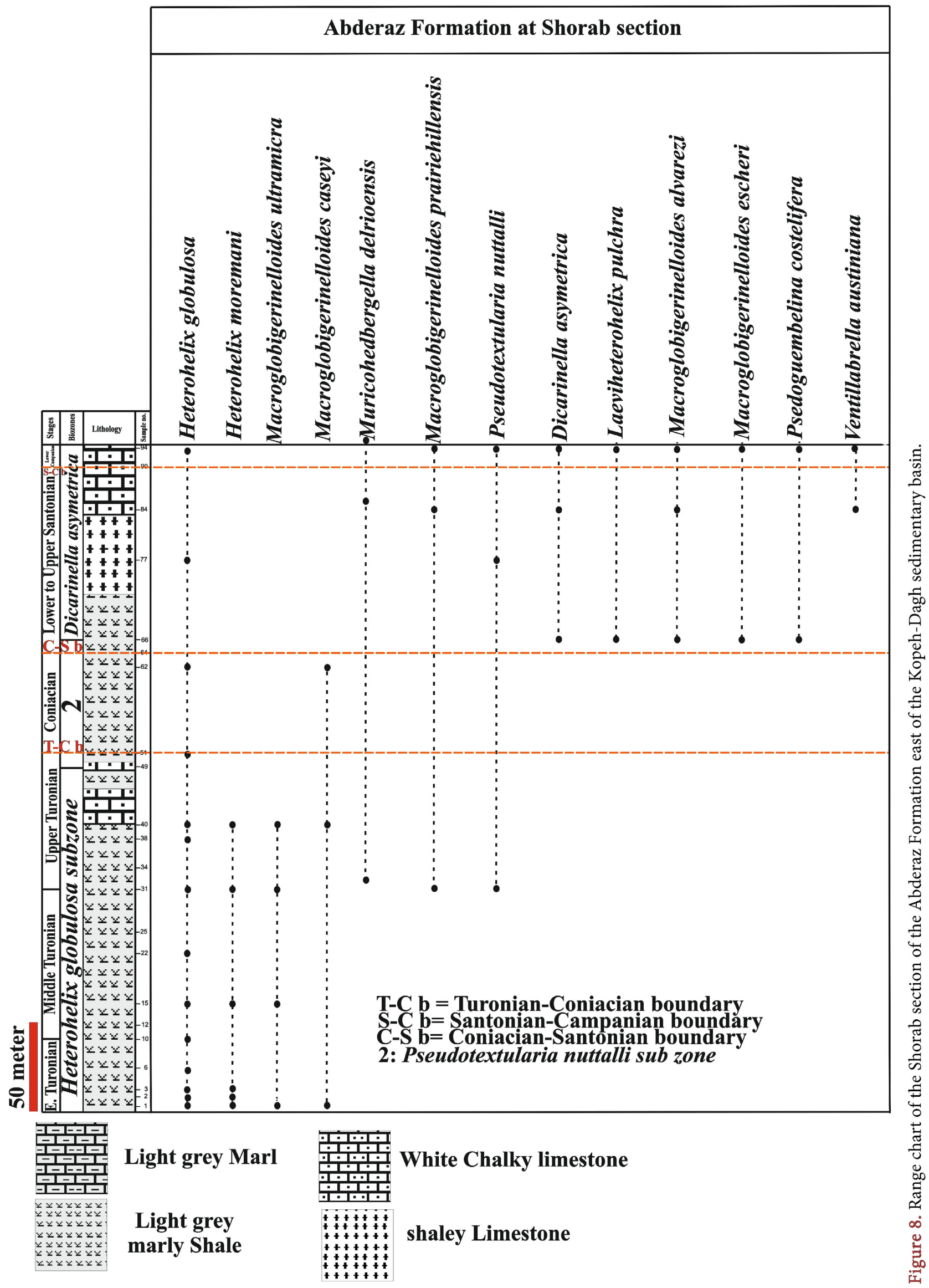


In the Shorab section, the FODs of Archaeoglobigerina cretacea and Dicarinella concavata, were used to detect the base of the Coniacian stage, whereas the LODs of Dicarinella primitiva and the Whiteinellids group and the FODs of Dicarinella asymetrica and Inoceramus aff. vistulensis determined the base of the Santonian stage. The FODs of Globotruncanita elevata and Ventilabrella austiniana and the extinction of the Marginotruncanid group were used to identify the base of the Campanian stage.

Ultimately, six sections of the Abderaz Formation, which is located east and center of the Kopeh-Dagh sedimentary basin in northeastern Iran, were correlated based on planktonic foraminifera in this study (Figure 9 and Figure 10).

\subsection{Turonian-Coniacian (T/C) Boundary}

In 2001, [32] recorded the first occurrence of the ammonite species Prionocycloceras milticostatum as an index species for the Turonian-Coniacian boundary. While the majority of those who study planktonic foraminifera have generally believed that the Turonian-Coniacian boundary cannot be determined based on planktonic foraminifera, others have held that the first occurrence of Marginotruncana sinuosa is an indication of the Turonian-Coniacian boundary [33] [34] [35]. Furthermore, [32] introduced a supplementary planktonic foraminifera species named Muricohedbergella flandrini, which was used for cases in which Dicarinella primitiva was not found. In addition, some authors have argued that the last occurrence of the planktonic foraminifera species Muricohedbergella simplex and Dicarinella primitiva took place before the first occurrence of Dicarinella concavata (Koutsoukos and Bengtson, 1993). However, the first occurrence of the inoceramid species Cremnoceramus deformis erectus has been used to identify the Turonian-Coniacian boundary [36] [37] [38].

In a major symposium concerning Cretaceous boundaries held in Brussels in 1995, the FOD of C. deformis erectus was used as a first marker species for the base of the Coniacian stage. Additionally, the FOD of Cremnoceramus deformis deformis has been shown to correspond to the earliest Coniacian stage found worldwide (Dochev, 2006). In the area analyzed in this study, the first occurrence of Dicarinella primitiva has been detected below the first occurrence of Cremnoceramus deformis deformis. Therefore, the FO of Di. primitiva was dated to the upper Turonian substage. In addition, the first occurrence of Marginotroncana paraconcavata has been dated to the Coniacian-Santonian boundary (Caron, 1985). In the study areas, the FO of $M$. paraconcavata took place in the Dicarinella primitiva Interval Range Zone (upper Turonian). Marginotruncana paraconcavata and Costellagerina pilula indicate the Turonian-Coniacian boundary in Iran. The Turonian-Coniacian boundary was detected in the Qarehso section based on the FOD of Dicarinella concavata. The base of the Coniacian stage was detected in the Abderaz village section based on the FODs of Contusotruncana fornicata and C. pateliformis. The base of the Coniacian stage was detected just below the first occurrence of Cremnoceramus deformis deformis in the Muzduran section. In the Shorab section, the base of the Coniacian 


\begin{tabular}{|c|c|c|c|c|c|c|c|c|c|c|c|}
\hline $\begin{array}{c}\text { LI0Z } \\
\text { !U } \\
\text { uo!̣หu.ıо } \\
\text { ze.IәpqV }\end{array}$ & 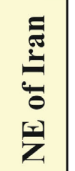 & \multicolumn{2}{|c|}{ 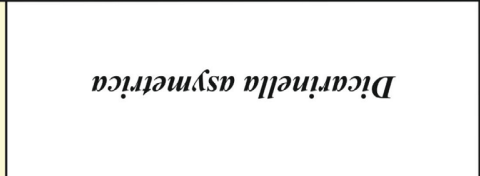 } & \multicolumn{5}{|c|}{ !прұпи р!.ирпџхәюрпод } & \multicolumn{3}{|c|}{ 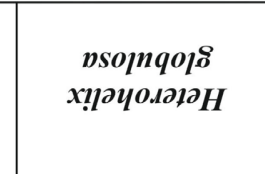 } \\
\hline 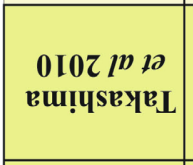 & 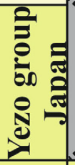 & & $\begin{array}{c}\text { Dग.1p } \\
\text { вupगun.110qol. }\end{array}$ & ن & $\begin{array}{r}\text { nso1 } \\
\text { quวun.l }\end{array}$ & & 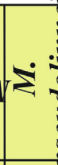 & "ू. & & $\frac{\sqrt{2}}{2}$ & \multirow[b]{2}{*}{ 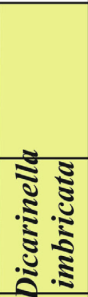 } \\
\hline $\begin{array}{c}\angle 00 Z \\
\text { Аәчगช् } \\
\text { вАо.!!ய! }\end{array}$ & 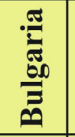 & ฉұркวอ & 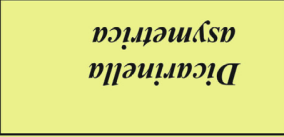 & \multicolumn{3}{|c|}{ 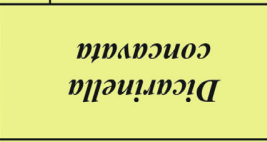 } & \multicolumn{2}{|c|}{ 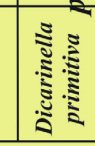 } & & 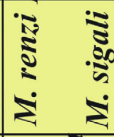 & \\
\hline 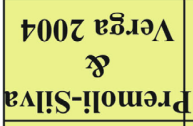 & $\circlearrowright$ & прทьวр & 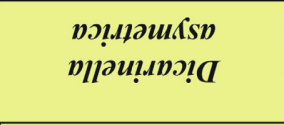 & \multicolumn{5}{|c|}{ 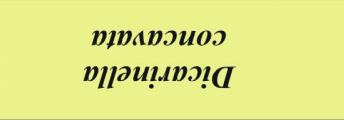 } & 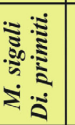 & 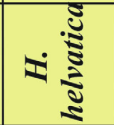 & \\
\hline 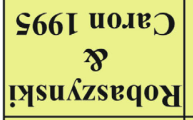 & $\stackrel{n}{\pi}$ & рұркวра & 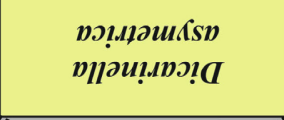 & \multicolumn{5}{|c|}{ 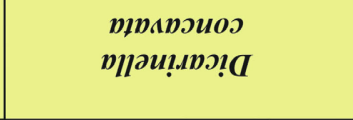 } & ¿ & \multicolumn{2}{|c|}{ 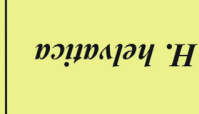 } \\
\hline 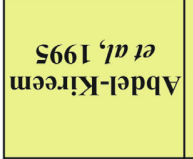 & $\sum_{00}^{0}$ & рұркวן & & \multicolumn{3}{|c|}{ 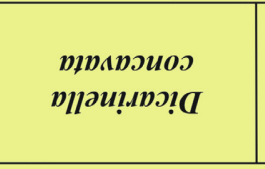 } & \multicolumn{2}{|c|}{ 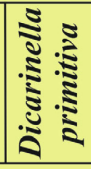 } & 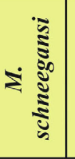 & 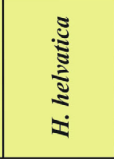 & 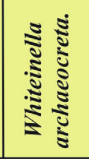 \\
\hline $\begin{array}{l}\text { 686I } \\
. \text {.ә†!IS }\end{array}$ & $\circlearrowleft$ & прจкวן & 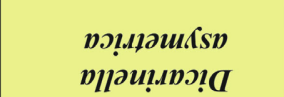 & \multicolumn{5}{|c|}{ 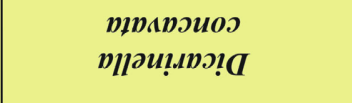 } & \multicolumn{3}{|c|}{ 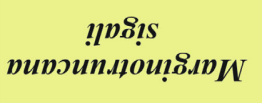 } \\
\hline $\begin{array}{l}\text { S86I } \\
\text { uo.Iv? }\end{array}$ & 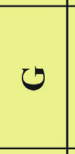 & пาทкวр & 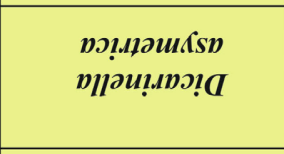 & \multicolumn{3}{|c|}{ 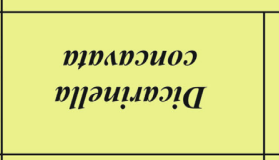 } & \multicolumn{2}{|c|}{ 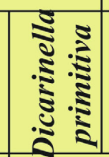 } & 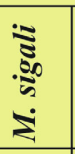 & 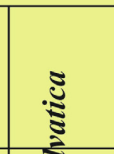 & 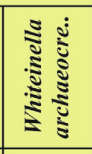 \\
\hline $\begin{array}{r}\text { †86I ' } p \text { p po } \\
\text { !ysuKzseqoy }\end{array}$ & 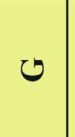 & рұркวן & 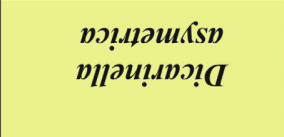 & \multirow{2}{*}{\multicolumn{5}{|c|}{ 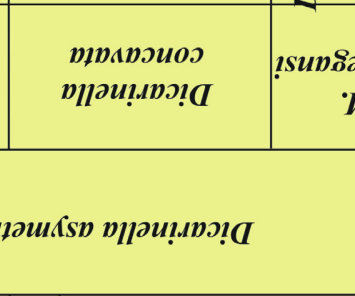 }} & & $\frac{2}{2}$ & 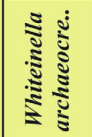 \\
\hline $\begin{array}{l}\text { L66I'086I } \\
\text { [e[eS }\end{array}$ & 高 & пұркวрว & 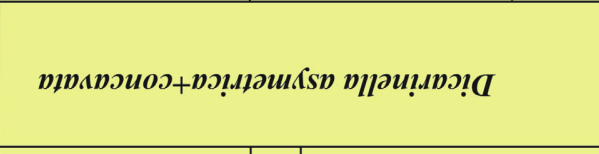 & & & & & & 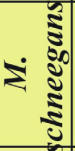 & 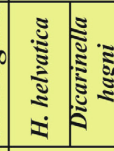 & 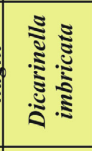 \\
\hline $\begin{array}{c}\text { 086I } \\
\text { S.эәршом }\end{array}$ & 离 & рาркวอ & 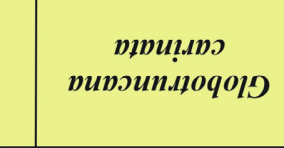 & 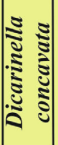 & \multicolumn{4}{|c|}{ 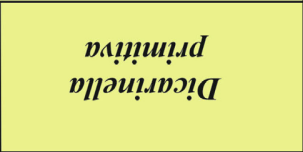 } & 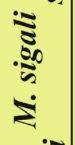 & $\sqrt{\pi}$ & 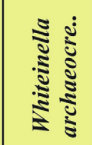 \\
\hline LL6I [ยסิ!S & : & 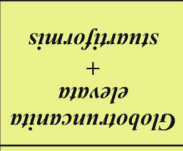 & 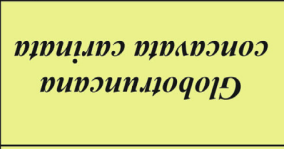 & \multicolumn{3}{|c|}{$\begin{array}{l}\text { рұрарวиоว } \\
\text { рпวน!.เрว! }\end{array}$} & \multicolumn{3}{|c|}{ 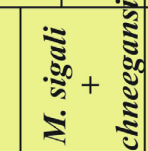 } & $\frac{2}{2}$ & ถัป \\
\hline 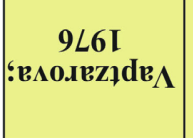 & 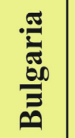 & прикวра & \multicolumn{2}{|l|}{ 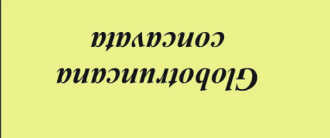 } & \multicolumn{5}{|c|}{ 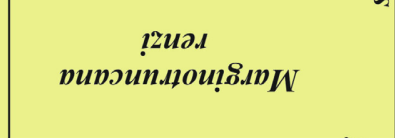 } & \multicolumn{2}{|c|}{ ропрхуру $H$} \\
\hline 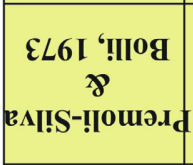 & 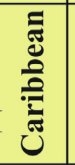 & рұркоро & 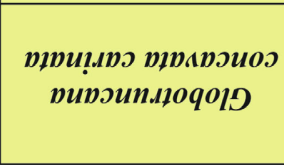 & \multicolumn{3}{|c|}{ 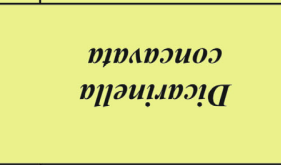 } & \multicolumn{3}{|c|}{ 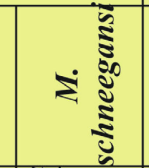 } & \multicolumn{2}{|c|}{$\begin{array}{c}\text { pəz!̣ธิовวә.I } \\
10 \mathrm{~N}\end{array}$} \\
\hline ZL6I J.IBg & $\frac{\pi}{3}$ & \multicolumn{3}{|c|}{ 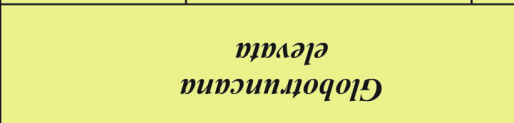 } & \multicolumn{2}{|c|}{ 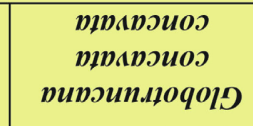 } & & $\begin{array}{l}5 \\
5 \\
\text { ș } \\
\text { s } \\
8\end{array}$ & 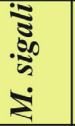 & \multicolumn{2}{|c|}{ рว!рхуру $\mathrm{H}$} \\
\hline \multicolumn{2}{|c|}{ səoิвาS-qns } & 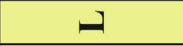 & $\triangleright$ & - & $\triangleright$ & $\sum$ & & ב & $\triangleright$ & $\sum$ & $\boldsymbol{\nu}$ \\
\hline วริยาง & & ur!̣urdur & Uв!ேU0मUвS & & Uв! & 103 & & & & B!Uo.In」 & \\
\hline
\end{tabular}




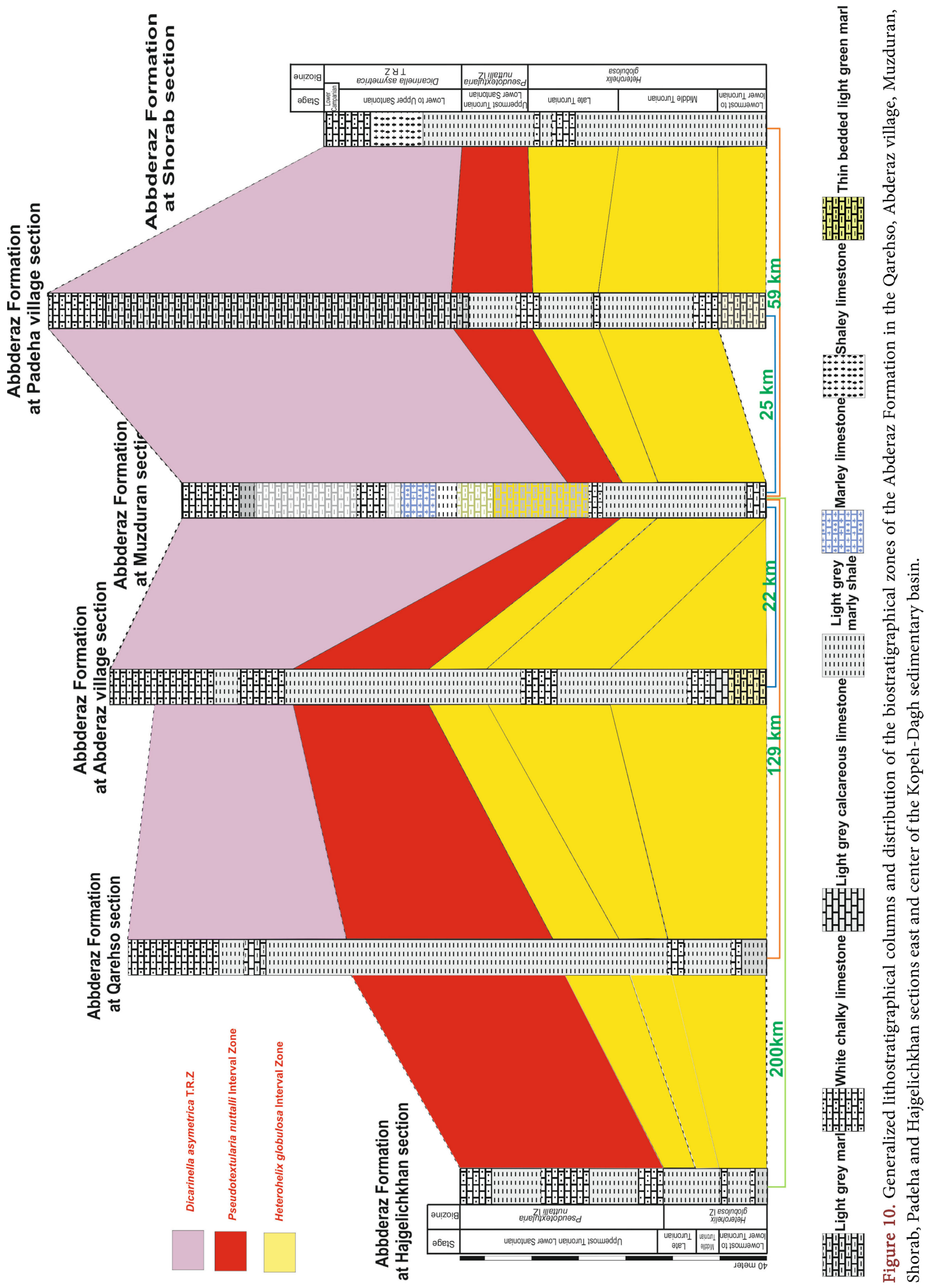


stage was identified based on the FODs of the planktonic foraminifera Archaeoglobigerina cretacea and Dicarinella concavata.

Recently, the Coniacian Working Group (CWG) of the Cretaceous subcommission on stratigraphy recommended that the first occurrence of Cremnoceramus rotundatus, an inoceramid bivalve, be used to define the Turonian-Coniacian boundary [35]. The first occurrence of Cremnoceramus deformis erectus is the primary marker used to identify the Turonian-Coniacian boundary in the literature [36] [37] [38] [39]. C. deformis erectus was not found in the Qarehso section of the Abderaz Formation. The FO of Dicarinella concavata and Dicarinella primitiva was found below the FO of Cremnoceramus deformis deformis in the study sections, so the upper Turonian substage was assigned to the Dicarinella concavata Range Zone in the study area. Consequently, the Turonian-Coniacian and Coniacian-Santonian boundaries have been placed in this zone. In addition, the first occurrence of Cremnoceramus walterdorfensis walterdorfensis has been used to indicate the uppermost Turonian [36]. Cremnoceramus walterdorfensis walterdorfensis and Cremnoceramus deformis deformis were recorded at sample numbers 44 and 45, respectively, and the Turonian- Coniacian boundary was placed at sample 45 in the Qarehso section. Cremnoceramus walterdorfensis walterdorfensis and Cremnoceramus deformis deformis were recorded at sample numbers 71 and 72, respectively, and the Turonian-Coniacian boundary was placed at sample 71 in the Abderaz village section.

Cremnoceramus walterdorfensis walterdorfensis and Cremnoceramus deformis deformis were recorded at sample numbers 40 and 50, respectively, and the Turonian-Coniacian boundary was placed at sample 41 in the Muzduran section.

Cremnoceramus walterdorfensis walterdorfensis was recorded at sample number 49, and the Turonian-Coniacian boundary was placed at sample 51 in the Shorab section. Cremnoceramus deformis deformis was not detected in this section. Also the Turonian-Coniacian boundary were placed at samples 72 and 67 respectively in the Hajgelichkhan and padeha village sections.

\subsection{Coniacian-Santonian (C/S) Boundary}

The first occurrence of the inoceramid species Cladoceramus undulatoplicatus has been used to identify the Coniacian-Santonian boundary [40]-[47]. The Santonian Working Group (SWG) recommends that the lowest occurrence of Cladoceramus undulatoplicatus be used as a marker for the Coniacian-Santonian boundary. At this time, the SWG cannot make a formal proposal for a Boundary Stratotype Section because the biostratigraphy must first be better understood and integrated. Three candidates for a Boundary Stratotype Section, Olazagutia Quarry (Navarra, Spain), Seaford Head (Sussex, England) and Ten Mile Creek (Dallas, Texas, USA), have been selected for further study. The primary marker of the Coniacian-Santonian boundary is the lowest occurrence of Cladoceramus undulatoplicatus, which is a taxon that is easily recognizable and widespread. Cladoceramus undulatoplicatus is found in North America, Europe, Africa, Madagascar and Central Asia. 
The secondary marker of the Coniacian-Santonian boundary is Sigalia carpatica. This planktonic foraminifera species is widespread in the Mediterranean region of the Tethys. Sigalia carpatica is associated with Inoceramus siccensis and Texanites in Tunisia. In northern Spain (Navarra), this species is found very close to the lowest occurrence of Cladoceramus undulatoplicatus. In the areas analyzed in this study, Cladoceramus undulatoplicatus was not found; therefore, the first occurrence of Echinocurys gr. scutata was used as a secondary marker [40] to identify the C/S boundary. In conclusion, based on the FOs of E. gr. scutata and pillbox Globotruncana linneiana (planktonic foraminifera), the Coniacian-Santonian boundary was placed at sample number 87 in the Qarehso section, at sample number 99 in the Abderaz village section, at sample number 53 in the Muzduran section, at sample number 64 in the Shorab section, at sample number 246 in the Hajgelichkhan section and at sample number 85 in the Padeha village section of the Abderaz Formation.

\subsection{Santonian-Campanian (S/C) Boundary}

Using of various marine fossil groups to define the Santonian-Campanian boundary differ considerably in relative age and position. The most widely recognized criterion is the extinction of the distinctive crinoid Marsupites testudinarius (found in North America, Europe, Asia, North Africa and Australia), which coincides exactly with two separate definitions of the boundary: the appearance of the ammonite Placenticeras bidorsatum and that of the belemnite Gonioteuthis granulataquadrata. This extinction may also coincide with a third definition of the boundary, the entry of the planktonic foraminifera Globotruncanita elevata. The base of magnetochron 33R, generally considered to coincide with, or to fall just above, the base of the Campanian, is shown to lie within the upper Santonian Uintacrinus socialis Zone [48]. In the area analyzed in this study, the extinction of the Marginotruncanid group together with the LOD of Pseudotextularia nuttalii identify the base of the Campanian stage in the Abderaz Village section. In contrast, the FODs of Globotruncanita elevata and Ventilabrella austiniana and the extinction of the Marginotruncanid group were used to identify the base of the Campanian stage in the Shorab section.

The base of the Campanian stage is indicated by the LODs of the Marginotruncanids groups and Ventilabrella austiniana in the Muzduran section. Whereas the Santonian-Campanian boundary was not detected in the Qarehso section, this boundary was found in the Abderaz village, Muzduran, Shorab and padeha village sections at sample numbers $130,99,90$ and 185 respectively.

\section{Conclusions}

The results of a recent study of six sections of the Abderaz Formation, east and Center of the Kopeh-Dagh sedimentary basin, can be summarized as follows:

1) In the Qarehso section of the Abderaz Formation, 77 species belonging to 18 genera, 8 inoceramid species belonging to 5 genera were found. Based on this faunal content, lowermost Turonian-upper Santonian ages were designated 
for that section of the formation. Two stage boundaries (the Turonian-Conician and Coniacian-Santonian) were recognized in the Qarehso section. The Turonian-Conician boundary was detected based on the FOD Dicarinella concavata, and the base of the Santonian stage was based on the FODs of Di. asymetrica found in the Qarehso section.

2) In the Abderaz village section of the Abderaz Formation, which is approximately 556.5 meters thick, 68 species belonging to 17 planktonic foraminifera genera, 9 inoceramid species belonging to 3 genera were recorded. The fossil assemblage in this section covered the lowermost Turonian-lowermost Campanian ages. In the Abderaz village section, three boundaries were detected. Based on the FODs of Contusotruncana fornicata and C. pateliformis, the base of the Coniacian stage was identified. Based on the FODs of Di. asymetrica and Macroglobigerinelloides alvarezi, the Coniacian-Santonian boundary was identified. Finally, using the extinction of the Marginotruncanid group and the LOD of Pseudotextularia nuttalii, the base of the Campanian stage was identified.

3) In the Muzduran section of the Abderaz Formation, which is 520 meters thick, 59 planktonic foraminifera species belonging to 19 genera, 10 inoceramid species belonging to 5 genera were identified. Based on this faunal content, an age of Middle Turonian-early Campanian is estimated for this section of the formation. In the Muzduran section, the base of the Coniacian stage was identified just below the first occurrence of Cremnoceramus deformis deformis, whereas the bases of the Santonian and Campanian stages were recorded at the FO of Echinocorys ex. gr. scutata and the LODs of the Marginotruncanids groups and Ventilabrella austiniana, respectively.

4) In the Shorab section of the Abderaz Formation, which is 360 meters thick, 51 planktonic foraminifera species belonging to 16 genera and 8 inoceramid species belonging to 4 genera were found. This fossil assemblage covers the entirety of the lowermost Turonian-early Campanian. Using the main bioevents in this section, three boundaries were found in the Shorab section: the Turonian-Coniacian, Coniacian-Santonian and Santonian-Campanian boundaries. Based on the FODs of Archaeoglobigerina cretacea and Dicarinella concavata the base of the Coniacian stage was identified. Using the FODs of the Globotruncanid group, Dicarinella asymetrica, the base of the Santonian stage was determined. Using the FODs of Globotruncanita elevata and Ventilabrella austiniana, along with the extinction of the Marginotruncanid group, the base of the Campanian stage in the Shorab section was identified.

5) In the Hajgelichkhan section of the Abderaz Formation, which is $261 / 5$ meters thick, 25 planktonic foraminifera species belonging to 11 genera and 8 inoceramid species belonging to 4 genera were found. This fossil assemblage covers the entirety of the lowermost Turonian-earliest Santonian.

6) In the Padeha village section of the Abderaz Formation, which is 600 meters thick, 54 planktonic foraminifera species belonging to 15 genera and 8 inoceramid species belonging to 4 genera were found. This fossil assemblage covers the entirety of the lowermost Turonian-early Campanian. 


\section{Acknowledgements}

This research was funded by the Ferdowsi University of Mashhad, project 2/39374.

\section{References}

[1] Moussavi-Harami, R. and Brenner, R. (1992) Geohistory Analysis and Petroleum Reservoir Characteristics of Lower Cretaceous (Neocomian) Sandstones, Eastern Kopet Dagh Basin, Northeastern Iran. Bulletin of the American Association of Petroleum Geologists, 76, 1200-1208.

[2] Shafiee Ardestani, M., Vahidinia, M. and Youssef, M. (2011) Biostratigraphy and Foraminiferal Bioevents of the Abderaz Formation (Middle Turonian-Lower Campanian) in Kopeh-Dagh Sedimentary Basin, Northeastern Iran. Egyptian Journal of Paleontology, 11, 1-16.

[3] Afshar-Harb, A. (1994) Geology of Kopet Dagh. In: Hushmandzadeh, A., Ed., Treatise on the Geology of Iran, Geological Survey of Iran, Tehran, 275 p. (In Persian)

[4] Vahidinia, M. (1994) Biostratigraphy \& Microfacies of Abderaz Formation at Eastern Kopet Daghbasin. Thesis. (In Persian)

[5] Foroghi, F. (2004) Microbiostratigraphy of Abderaz Formation in Eastern (North, NE Mashhad). Thesis, Shahid Beheshti University. (In Persian)

[6] Zepeda, M.A. (1998) Planktic Foraminifera Diversity, Equitability and Biostratigraphy of the Uppermost Campanian-Maastrichtian, ODP Leg122, Hole 762C, Exmoth Plateau, NW Australia, Eastern Indian Ocean. Cretaceous Research, 19, 117 152.

[7] Peryt, D. and Lamolda, M.A. (2002) Benthic Foraminifers from the ConiacianSantonian Boundary Interval at Olazagutia, Spain. In: Lamolda, M.A., Comp., Meeting on the Coniacian-Santonian Boundary, Bilbao, 14-16 September 2002, Abstracts and Field Guide Book, 19.

[8] Bolli H.M. (1957) The genera Praeglobotruncana, Globotruncana, Rotalipora Abathomphalus in the Upper Cretaceous of Trinidad, B.W.I.U.S. Natural History Museum Bulletin, No. 215, 51-60.

[9] Postuma, J. (1971) Manual of Planktonic Foraminifera. Elsevier Publishing Company, Amsterdam, 420.

[10] Robaszynski, F. and Caron, M. (1979) Atlas de foraminifèrs planctoniques du Crétacémoyen (Mer Boreale et Tethys), première partie. Cahiers de Micropaleontologie, 1, 1-185.

[11] Robaszynski, F. and Caron, M. (1995) Foraminifers planktonique du cretace. Bulletin Society Geological of France, 166, 681-698.

[12] Premoli Silva, I. and Sliter, W.V. (1995) Cretaceous Planktonic Foraminiferal Biostratigraphy and Evolutionary Trends from the Bottaccione Section, Gubbio, Italy. Paleontographia Italica, 82, 1-89.

[13] Loeblich Jr., A.R. and Tappan, E. (1988) Foraminiferal Genera and Their Classification. Van Nostrand Reinhold Company, New York, 970 p. https://doi.org/10.1007/978-1-4899-5760-3

[14] Ellis, B.F. and Messina, A.R. (1999) Catalogue of Foraminifera on CD ROM. American Museum of Natural History.

[15] Premoli Silva, I. and Verga, D. (2004) Practical Manual of Cretaceous Planktonic Foraminifera. In: Verga, D. and Rettori, R., Eds., International School on Planktonic 
Foraminifera, Universities of Perugia and Milano, Tipografia Pontefelcino, Perugia, $283 \mathrm{p}$.

[16] Walaszczyk, I. and Wood, C.J. (1999) Inoceramids and Biostratigraphy at the Turonian/Coniacian Boundary; Based on the Salzgitter-Salder Quarry, Lower Saxony, Germany and the Sחupia Nadbrzëna Section, Central Poland. Acta Geologica Polonica, 48, 395-434.

[17] Wood, C.J., Walaszczyk, I., Mortimore, R.N. and Woods, M.A. (2004) New Observations on the Inoceramid Biostratigraphy of the Higher Part of the Upper Turonian and the Turonian-Coniacian Boundary Transition in Poland, Germany and the UK. Acta Geologica Polonica, 54, 541-549.

[18] Walaszczyk, I. and Cobban, W.A. (2007) Inoceramid Fauna and Biostratigraphy of the Upper Middle Coniacian-Lower Middle Santonian of the Pueblo Section (SE Colorado, US Western Interior). Cretaceous Research, 28, 132-142.

[19] Barr, F.T. (1972) Cretaceous Biostratigraphy and Planktonic Foraminifera of Libya. Micropaleontology, 18, 1-46. https://doi.org/10.2307/1484977

[20] Premoli Silva, I. and Bolli, H.M. (1973) Late Cretaceous to Eocene Planktonic Foraminifera and Stratigraphy of Leg 15 Sites in the Caribbean Sea. Deep Sea Drilling Project Reports and Publication, 15, 499-547.

[21] Vaptzarova, Y. (1976) Zonation du Crétacé supérieur du type Carpatique en Bulgarie du Nord-Ouest d'apres les Foraminiferes planctoniques. Geologica Balcanica, 6, 93-109.

[22] Sigal J. (1977) Essai du zonation du Cretace mediterraneenne an 1 aide des foraminiferes planctoniquess. Geologie Mediterraneenne, 4, 99-108.

[23] Wonders, A.A. (1980) Middle and late Cretaceous planktonic Foraminifera of the western Mediterranean area. Utrecht Micropaleontology Bulletin, 24, 1-158.

[24] Salaj, J. (1980) Microbiostratigraphie du Crétacé et du Paléogène de la Tunisie Septentrionale et Orientale (Hypostratotypes Tunisiens). Institut Géologique de Dionzystur, Bratislava, $238 \mathrm{p}$.

[25] Salaj, J. (1997) Microbiostratigraphical (Foraminifera) Division of the Turonian to Santonian in Tunisia (El Kef and Dj. Fguira Salah Area). Geologica Carpathica, 48, 171-178.

[26] Robaszynski, F., Caron, M., Gonzalez Donoso, J.M. and Wonders, A.A.H. (1984) Atlas of Late Cretaceous Globotruncanids. Revue de Micropaléontologie, 26, 145305.

[27] Caron, M. (1985) Cretaceous Planktic Foraminifera. In: Bolli, H.M., Saunders, J.B. and Perch Nielsen, K., Eds., Plankton Stratigraphy, Cambridge University Press, Cambridge, 17-86.

[28] Sliter, W.V. (1989) Biostratigraphic Zonation for Cretaceous Planktonic Foraminifers Examined in Thin Section. Journal of Foraminiferal Research, 19, 1-19.

[29] Abdel-Kireem, M.R., Samir, A.M. and Ibrahim, M.I.A. (1995) Upper Cretaceous Planktonic Foraminiferal Zonation and Correlation in the Northern Part of Western Desert, Egypt. Neues Jahrbuch für Geologie und Paläontologie, Abh., 198, 329361.

[30] Dimitrova, E. and Valchev, B. (2007) Attempt for Upper Cretaceous Planktic Foraminiferal Zonation of the Srednogoriå and Eastern Balkan Zones (Bulgaria). Geologica Balcanica, 36, 55-63.

[31] Takashima, R., Nishi, H., Yamanaka, T., Hayashi, K., Waseda, A., Obuse, A., Tomosugi, T., Deguchi, N. and Mochizuki, S. (2010) High-Resolution Terrestrial Carbon Isotope \& Planktic Foraminiferal Records of the Upper Cenomanian to the 
Lower Campanian in the Northwest Pacific. Earth \& Planetary Science Letters, 289, 570-582.

[32] Gebhardt, H. (2001) Calcareous Nannofossils from the Nkalagu Formation Type Locality (Middle Turonian to Coniacian, Southern Nigeria): Biostratigraphy and Palæo-Ecologic Implications. Journal of African Earth Sciences, 32, 391-402.

[33] Birkelund, T., Hancock, J.M., Hart, M.B., Rawson, P.F., Remane, J., Robaszynski, F., Schmid, F. and Surlyk, F. (1984) Cretaceous Stage Boundaries-Proposals. Bulletin of the Geological Society of Denmark, 33, 3-20.

[34] Marks, P. (1984) Proposal for the Recognition of Boundaries between Cretaceous Stages by Means of Planktonic Foraminiferal Biostratigraphy. Bulletin of the Geological Society of Denmark, 33, 163-169.

[35] Kauffman, E.G., Kennedy, W.J. and Wood, C.J. (1996) The Coniacian Stage and Substage Boundaries. Bulletin de PInstitut Royal des Sciences Naturelles de Belgique, Sciences de la Terre, 66, 81-94.

[36] Walaszczyk. I. and Wood, C.J. (2008) Turonian-Coniacian Boundary; Definition, Recognition and Stratotype Problems. International Geological Congress, Oslo, 6-14 August2008.

[37] Wood, C.J., Ernst, G. and Rasemann, G. (1984) The Turonian-Coniacian Stage Boundary in Lower Saxony (Germany) and Adjacent Areas: The Salzgitter-Salder Quarry as a Proposed International Standard Section. Bulletin of Geological Society of Denmark, 33, 225-238.

[38] Walaszczyk, I. and Wood, C.J. (2000) Inoceramid Bivalves at the Turonian/Coniacian Boundary: Biostratigraphy, Events and Diversity Trends. Acta Geologica Polonica, 50, 421-430.

[39] Dochev, D. (2006) New Biostratigraphic Data Based on Inoceramid Bivalves from the Interval Upper Turonian-Coniacian in Breznik, West Srednogorie Mountains, Bulgaria. Geosciences, 61-64.

[40] Gallemí, J., López, G., Martínez, R. and Pons, J.M. (2007) Macrofauna of the Cantera de Margas Section, Olazagutia: Coniacian/Santonian Boundary, Navarro-Cantabrian Basin, Northern Spain. Cretaceous Research, 28, 5-17.

[41] Hampton, M.J., Bailey, H.W., Gallagher, L.T., Mortimore, R.N. and Wood, C.J. (2007) The Biostratigraphy of Seaford Head, Sussex, Southern England; an International Reference Section for the Basal Boundaries for the Santonian and Campanian Stages in Chalk Facies. Cretaceous Research, 28, 46-60.

[42] Ion, J. and Szasz, L. (1994) Biostratigraphy of the Upper Cretaceous of Romania. Cretaceous Research, 15, 59-87.

[43] Kopaevich, L.F., Beniamovski, V.N. and Sadekov, A.Yu. (2007) Middle Coniacian-Santonian Foraminiferal Bioevents around the Mangyshlak Peninsula and Russian Platform. Cretaceous Research, 28, 108-118.

[44] Lamolda, M.A. and Hancock, J.M. (1996) The Santonian Stage and Substages. Bulletin de I Institut Royal des Sciences Naturelles de Belgique, Sciences de la Terre, 66, 95-102.

[45] Lamolda, M.A. and Paul, C.R.C. (2007) Carbon and Oxygen Stable Isotopes across the Coniacian/Santonian Boundary at Olazagutia, Northern Spain. Cretaceous Research, 28, 37-45.

[46] Melinte, M.C. and Lamolda, M.A. (2007) Calcareous Nannofossil Biostratigraphy of the Coniacian/Santonian Boundary Interval in Romania and Comparison with Other European Regions. Cretaceous Research, 28, 119-127.

[47] Peryt, D. and Lamolda, M.A. (2007) Neoflabellinids (Benthic Foraminifers) from 
the Upper Coniacian and Lower Santonian at Olazagutia, Navarra Province, Spain; Taxonomy and Correlation Potential. Cretaceous Research, 28, 30-36.

[48] Gale, A.S., Montgomery, P., Kennedy, W.J., Hancock, J.M., Burnett, J.A. and McArthur, J.M. (1995) Definition and Global Correlation of the Santonian-Campanian Boundary. Terra Nova, 7, 611-622.

https://doi.org/10.1111/j.1365-3121.1995.tb00710.x 